\title{
Anti-inflammatory and Analgesic Potential of Acetone Leaf Extract of Combretum Sordidum and its Fractions
}

\author{
Babatunde B. Samuel ${ }^{1 *}$, Olayinka A. Oridupa ${ }^{2}$, Fisayo Gbadegesin ${ }^{1}$ \\ 1 Department of Pharmaceutical Chemistry, Faculty of Pharmacy, University of Ibadan. \\ 2Department of Veterinary Pharmacology and Toxicology, Faculty of Veterinary Medicine, University of Ibadan.
}

\begin{abstract}
Combretum species are traditionally used in treatment of arthritis, fungal and bacterial infections. This study investigated anti-inflammatory activity of $C$. sordidum acetone extract in egg albumen-induced paw oedema and formalin paw lick test in rats, while analgesic activity was determined by acetic acid-induced abdominal writhing test in mouse. Bioactivity guided analgesic effect were also carried out on solvent-solvent partitioned and chromatographic fractions. Rats administered with extract progressively showed significant reduction in oedema formation 60 minutes post-induction. Dose-dependent inhibition of formalin-induced paw lick was observed at early and late phases of the experiment compared to indomethacin. Abdominal writhing was significantly inhibited with $400 \mathrm{mg} / \mathrm{kg}$ extract effect $(73.1 \%)$ comparable to aspirin (75.9\%). Most active chromatographic fraction identified as F7 (79.5\%) showed significant analgesic activity, higher than aspirin (55.0\%). Results established anti-inflammatory and analgesic of C. sordidum. Further studies are on-going to identify and characterize the bioactive principle responsible for these pharmacological effects.
\end{abstract}

Keywords: Combretum sordidum, Anti-inflammatory, Analgesic, Bioactivity-guided separation

\section{INTRODUCTION}

In recent years, the search for phytochemicals with antioxidant, anti-inflammatory and analgesic properties have been on the rise due to their potential use in the therapy of various chronic and infectious diseases..$^{1,2}$ Many diseases originate from uncontrolled or unregulated inflammatory process in the body. ${ }^{3}$ Inf-

\footnotetext{
*Corresponding Author: Babatunde B. Samuel, e-mail: tundebsamuel@gmail.com Babatunde B. Samuel ORCID Number: 0000-0002-1834-9548

Olayinka A. Oridupa ORCID Number: 0000-0002-6435-6925

Fisayo Gbadegesin ORCID Number: 0000-0003-1322-679X

(Received 10 September 2018, accepted 15 January 2019)
} 
lammation is a localized protective reaction of cells/tissues of the body to allergic or chemical irritation, injury and/or infections. ${ }^{4}$ Inflammation is characterized by pain, heat, redness, swelling and loss of function resulting from vasodilation and leading to an increased blood supply with increased influx of leukocytes, protein and fluids into intercellular spaces of the inflamed regions. ${ }^{5}$ Inflammatory responses occur as the body recognizes injury and prepare to repair the damage, but uncontrolled inflammation leads to development and progression of diseases and disorders which are manifested as exacerbated symptoms of inflammation. ${ }^{6,7,8}$

Since antiquity, medicinal plants such as plants in genus Combretum have been employed for treatment of inflammation, pain and related diseases. One of plants in the genus, Combretum sordidum Exell (Combretaceae) is so employed as traditional remedy of infectious and non-infectious ailments. ${ }^{9}$ C. sordidum a scandent shrub or a creeper with white flowers and easily recognized by the small red scales on the under-surface of the leaves..$^{10}$ They are widely distributed throughout South and West Africa. ${ }^{11}$ This plant and other members of the genus from different regions of Africa are traditionally used by local healers for treatment of diseases of inflammatory origin including conjunctivitis, abdominal disorders, backache, toothache, diabetes. ${ }^{12,13}$ It has been scientifically proven to have antiasthmatic, antimicrobial and antiplasmodic effects. ${ }^{14}$ Another member of the genus, $C$. molle R.Brex was reported to have cardiocascular effect ${ }^{15}$, anti-inflammatory and inhibitory effect on haematopoietic prostaglandin D2 synthase; while Combretum woodii have shown significant anti-infective activities. ${ }^{16,17,18}$

Despite the use of $C$. sordidum in traditional medicine, there is a dearth of knowledge on the medicinal and ethnopharmacological uses of $C$. sordidum in literature. This current study investigated the anti-inflammatory and analgesic potential of the acetone extract of Combretum sordidum. Its constituent fractions which were separated by solvent-solvent partitioning using n-hexane, ethyl acetate and methanol were also assessed for their analgesic effect and bioassay guided purification of the most potent fraction was carried out to isolate the bioactive compound responsible for its analgesic effect.

\section{METHODOLOGY}

\section{Preparation of plant extract}

Fresh leaves of Combretum sordidum were collected from Federal Research Institute of Nigeria (FRIN), Ibadan, Oyo state (Voucher No: 109923). The leaves were air dried and then pulverized. Acetone extract of the pulverized plant material was obtained by extracting $1 \mathrm{~kg}$ of the plant using a soxhlet extractor (hot extraction), after which it was concentrated using Buchi $\AA$ rotary evaporator at $40^{\circ} \mathrm{C}$. 


\section{Experimental Animal Model}

Wistar rats weighing 120-16og and mice weighing 15-20g were obtained and housed at the Experimental Animal Unit of Department of Veterinary Pharmacology and Toxicology, University of Ibadan. The rats were fed with standard pellets and allowed access to water ad libitum. The animals were divided into groups of five rats each and were fasted overnight before commencement of each experiment.

\section{Anti- inflammatory Activity of the crude extract}

\section{Egg albumen -induced Paw oedema in Rats}

In this model, following an overnight fasting, three doses C. sordidum leaf extracts $(100 \mathrm{mg} / \mathrm{kg}, 200 \mathrm{mg} / \mathrm{kg}$ and $400 \mathrm{mg} / \mathrm{kg}$ ) were orally administered to rats in three different treatment groups, and simultaneously, indomethacin (10mg/kg) was administered to animals in the reference group. Control animals received distilled water $(10 \mathrm{ml} / \mathrm{kg})$ only.

An hour after the treatment, egg albumen (0.2ml) was injected into the right paw of each rat under the sub plantar region. The paw sizes were measured before and at interval of 3omins, 6omins and 9omins after egg albumen injection by using the cotton thread method. The cotton thread was wrapped around the paw and the circumference was measured with a meter rule. Oedema formation was determined as indicator of inflammatory response in the injected paw.

The inhibition of oedema formation was calculated according to the formula;

\% inhibition $=[(\mathrm{C} 1-\mathrm{Co})$ control $-(\mathrm{C} 1-\mathrm{Co})$ test $] /(\mathrm{C} 1-\mathrm{Co})$ control X100

Where $\mathrm{Co}=$ Paw size at time zero minute

$\mathrm{C} 1=$ Paw size at time $\mathrm{t}$ minutes.

\section{Formalin Paw lick Test in Rats}

Following an overnight fast, the rats were also grouped and treated with the extracts were as in the experiment above. Thirty minutes after treatment, $25 \mu \mathrm{l}$ of $2.5 \%$ formalin was injected into the sub-planar surface of the rat paw. Responses were measured between o to 5 minutes after injection of formalin for the first phase response; while the second phase response was observed between 15 to 30 minutes after the injection. The licking of the paw by the rat is indicative of pain and the duration was counted in seconds as the response to inflammatory pain. 


\section{Analgesic Activity of the crude extract}

Acetic acid- induced abdominal writhing test was used to determine the analgesic property of the crude extract in mice. Five groups o mice were pretreatment with saline, extract $(100,200,400 \mathrm{mg} / \mathrm{kg})$, aspirin at $15 \mathrm{mg} / \mathrm{kg}$ and injected intraperitonially with $0.01 \mathrm{ml}$ of $0.6 \%$ acetic acid solution 60 minutes post-treatment. Five minutes post- injection of acetic acid, the number of writhing was observed and counted for the next twenty minutes and recorded. The inhibition of acetic acid- induced abdominal contractions is indicative of analgesic effect.

$\%$ inhibition $=($ Mean No. of writhing $)$ control $-($ Mean No. of writhing $)$ test $/$ Mean No of writhing) control X 100

\section{Solvent-solvent partitioning of the crude extract}

To carry out the solvent-solvent partitioning of the extract, $17 \mathrm{~g}$ of the crude extract was dissolved in $250 \mathrm{ml}$ of a mixture of solvents (15\% of methanol in water) in a Separating funnel. The dissolved extract in the separating funnel was partitioned with equal volume of hexane. After the collection of the hexane fraction; the methanol-water fraction was further fractionated with ethyl acetate to obtain the ethyl acetate fraction. Three major fractions were obtained which are hexane, ethyl acetate and water/methanol fractions. The analgesic activities of the three fractions were conducted at doses of $20 \mathrm{mg} / \mathrm{kg}$ and $50 \mathrm{mg} / \mathrm{kg}$ using Acetic acid- induced abdominal writhing test as described above. The result was compared to that of mice treated with aspirin $(15 \mathrm{mg} / \mathrm{kg})$.

\section{Column Chromatography of Hexane Fraction of $C$. sordidum}

Column chromatographic separation of the hexane fraction was carried out on silica gel stationary phase using the following order of mobile phases: hexane $100 \%$ followed by hexane: ethyl acetate (97.5:2.5), (95:5), (92.5:7.5), (90:10), (85:15), (80:20), (70:30), (60:40), (50:50), (40:60), (30:70), (20:80), (10:90), ethyl acetate $100 \%$ and methanol $100 \%$. A total of 175 fractions (30mL) were collected and combined on the basis of TLC fingerprint. Seven (7) major fractions labeled F1-F7 were obtained. The analgesic activity of the seven fractions was carried out at $10 \mathrm{mg} / \mathrm{kg}$ and $15 \mathrm{mg} / \mathrm{kg}$ to identify the compound responsible for the activity. The result was also compared to that obtained for mice administered with aspirin at $15 \mathrm{mg} / \mathrm{kg}$.

\section{Statistical Analysis}

All values are expressed as mean \pm S.E.M. Data was analyzed by one- way analysis of variance and two- way analysis of variance (ANOVA) followed by 
Dunnet and Tukey's multiple comparison tests using Graphpad prism (6) software. Differences of mean were considered at $\mathrm{p}<0.05$.

\section{RESULTS AND DISCUSSION}

\section{Anti-inflammatory and Analgesic Activities of the crude extract}

The initial change in paw size observed at o minute was primarily due to the volume of egg albumen injected into the rat paw. The rats administered with the acetone extract showed a dose-dependent inhibition of the paw oedema induced by the egg albumen. The inflammatory response in paw of rats administered with the extract at doses of $100 \mathrm{mg} / \mathrm{kg}(0.54 \pm 0.02 \mathrm{~cm}$ and $0.56 \pm 0.05 \mathrm{~cm})$, $200 \mathrm{mg} / \mathrm{kg}(0.84 \pm 0.12 \mathrm{~cm}$ and $0.44 \pm 0.11 \mathrm{~cm})$ and $400 \mathrm{mg} / \mathrm{kg}(0.84 \pm 0.12 \mathrm{~cm}$ and $0.52 \pm 0.07 \mathrm{~cm})$ were reduced compared to that of indomethacin $(1.04 \pm 0.3 \mathrm{~cm}$ and $0.86 \pm 0.08 \mathrm{~cm})$ at 30 minutes and 60 minutes post-injection, but the extract at $200 \mathrm{mg} / \mathrm{kg}$ dose inhibited $(0.26 \pm 0.11 \mathrm{~cm})$ oedema formation more significantly $(\mathrm{p}<0.05)$ compared to indomethacin $(0.42 \pm 0.1 \mathrm{~cm})$ at 90 minutes post- injection (Table 1).

Rats pretreated with the plant extract showed lesser response to pain at both phases of formalin paw lick model in a dose- dependent manner. Inhibition of the response to pain in rats administered with all the extract doses was comparable to that observed for rats administered with indomethacin in the early phase. At the late phase, rats treated with 200mg/ $\mathrm{kg}$ and $400 \mathrm{mg} / \mathrm{kg}$ doses showed significantly inhibition of response to pain (62\% and $64 \%$ respectively) compared to rats administered with indomethacin (37.3\%) (Table 2).

A dose-dependent inhibition of abdominal writhes was observed in mice administered with doses of the extract. The inhibition of abdominal writhing observed in mice administered 400mg/ $\mathrm{kg}(11.75 \pm 1.19)$ was comparable to mice administered aspirin (10.5 \pm 0.83 ). Pain expressed as abdominal writhes were significantly ( $\mathrm{p}<0.05)$ inhibited in all mice administered with the crude extract when compared to the negative control (untreated mice) (Table 3).

\section{Solvent-solvent partitioned fractions and analgesic activity}

Three different fractions were obtained from the solvent partitioned crude extract; hexane, ethyl acetate and methanol/water which gave 5.151, 4.793 and $5.468 \mathrm{~g}$ respectively. The fractions significantly inhibited abdominal writhes compared to the control mice, and the level of inhibition of the writhes was compared with aspirin at $15 \mathrm{mg} / \mathrm{kg}$ (42.8\%). Lower doses of the fractions (20mg/ $\mathrm{kg}$ ) showed better inhibition of abdominal writhes, with mice administered with hexane fraction $(20 \mathrm{mg} / \mathrm{kg})$ showed the highest percentage inhibiti- 
on (44.4\%) (Table 4). The analgesic activity of column fractions of the hexane extract at 10mg/kg showed F1- 46.09\%, F2- 48.45\%, F3- 43.94\%, F4- 43.94\%, F5- 57.88\%, F6- 74.89\%, F7- 79.51\%, hexane fraction- $63.88 \%$, while aspirin at $15 \mathrm{mg} / \mathrm{kg}$ had $54.99 \%$ (Fig 1).

Table 1. Paw size $(\mathrm{cm})$ and percentage oedema formation in rat paw injected with Egg albumen and pre-treated with Combretum sordidum extract

\begin{tabular}{|c|c|c|c|c|c|}
\hline Group & 0 minute & 30 minutes & 60 minutes & 90 minutes & 120 minutes \\
\hline Control & $\begin{array}{c}0.36 \pm 0.05 \\
(0 \%)\end{array}$ & $\begin{array}{c}0.62 \pm 0.12 \\
(72.2 \%)\end{array}$ & $\begin{array}{c}0.68 \pm 0.07 \\
(88.9 \%)\end{array}$ & $\begin{array}{l}0.82 \pm 0.09 \\
(127.8 \%)\end{array}$ & $\begin{array}{l}0.88 \pm 0.09 \\
(144.4 \%)\end{array}$ \\
\hline CS $100 \mathrm{mg} / \mathrm{kg}$ & $\begin{array}{c}0.46 \pm 0.06 \\
(0 \%)\end{array}$ & $\begin{array}{c}0.54 \pm 0.02 \\
(17.4 \%)\end{array}$ & $\begin{array}{c}0.56 \pm 0.05 \\
(21.7 \%)\end{array}$ & $\begin{array}{c}0.50 \pm 0.07 \\
(8.7 \%)\end{array}$ & $\begin{array}{c}0.50 \pm 0.07 \\
(8.7 \%)\end{array}$ \\
\hline CS 200mg/kg & $\begin{array}{c}0.38 \pm 0.06 \\
(0 \%)\end{array}$ & $\begin{array}{l}0.84 \pm 0.12 \\
(121.1 \%)\end{array}$ & $\begin{array}{c}0.44 \pm 0.11 \\
(15.8 \%)\end{array}$ & $\begin{array}{c}0.26 \pm 0.11 \\
(-31.6 \%)\end{array}$ & $\begin{array}{c}0.20 \pm 0.10 \\
(-47.4 \%)\end{array}$ \\
\hline CS 400mg/kg & $\begin{array}{c}0.34 \pm 0.04 \\
(0 \%)\end{array}$ & $\begin{array}{l}0.84 \pm 0.12 \\
(147.1 \%)\end{array}$ & $\begin{array}{c}0.52 \pm 0.07 \\
(52.9 \%)\end{array}$ & $\begin{array}{c}0.46 \pm 0.08 \\
(35.3 \%)\end{array}$ & $\begin{array}{c}0.20 \pm 0.09 \\
(-41.2 \%)\end{array}$ \\
\hline $\begin{array}{l}\text { Indomethacin } \\
10 \mathrm{mg} / \mathrm{kg}\end{array}$ & $\begin{array}{c}0.56 \pm 0.1 \\
(0 \%)\end{array}$ & $\begin{array}{l}1.04 \pm 0.3 \\
(85.7 \%)\end{array}$ & $\begin{array}{c}0.86 \pm 0.08 \\
(53.6 \%)\end{array}$ & $\begin{array}{c}0.42 \pm 0.1 \\
(-25 \%)\end{array}$ & $\begin{array}{c}0.38 \pm 0.08 \\
(-32.1 \%)\end{array}$ \\
\hline
\end{tabular}

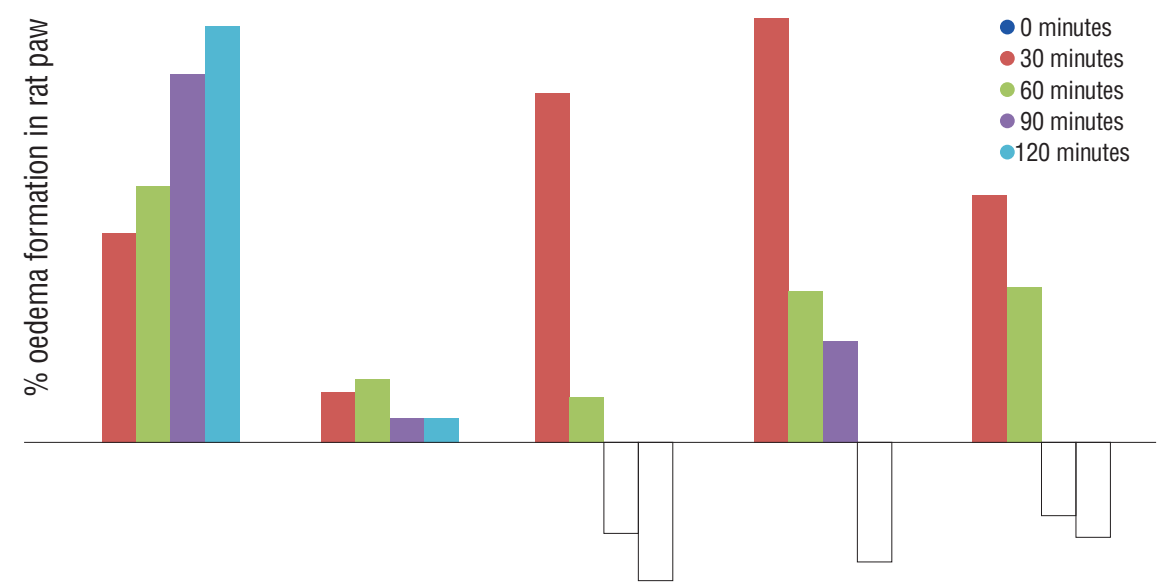

Different doses of extract, negative \& positive controls

Figure 1: Paw size $(\mathrm{cm})$ and percentage oedema formation in rat paw injected with Egg albumen and pre-treated with Combretum sordidum extract 
Table 2. Number of paw licks (and percentage inhibition of licks) in rats administered with formalin and pretreated with Combretum sordidum extract

\begin{tabular}{|l|l|l|}
\hline \multirow{2}{*}{ Groups } & \multicolumn{2}{|l|}{ Number of Licks } \\
\cline { 2 - 3 } & Early Phase (5 minutes) & Late Phase (20-25minutes) \\
\hline Control & $107.5 \pm 17.07(0 \%)$ & $75.0 \pm 5.37(0 \%)$ \\
\hline CS $100 \mathrm{mg} / \mathrm{kg}$ & $90.3 \pm 15.09(16.1 \%)$ & $68.25 \pm 6.73(9 \%)$ \\
\hline CS $200 \mathrm{mg} / \mathrm{kg}$ & $91.3 \pm 8.08(17.8 \%)$ & $28.5 \pm 6.38(62 \%)$ \\
\hline CS $400 \mathrm{mg} / \mathrm{kg}$ & $81.8 \pm 3.89(23.95 \%)$ & $27.0 \pm 9.57(64 \%)$ \\
\hline Indomethacin $10 \mathrm{mg} / \mathrm{kg}$ & $88.5 \pm 1.03(17.7 \%)$ & $47.0 \pm 7.50(37.3 \%)$ \\
\hline
\end{tabular}

- Early phase (5 minutes)

- Late phase (20-25 minutes)

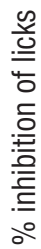

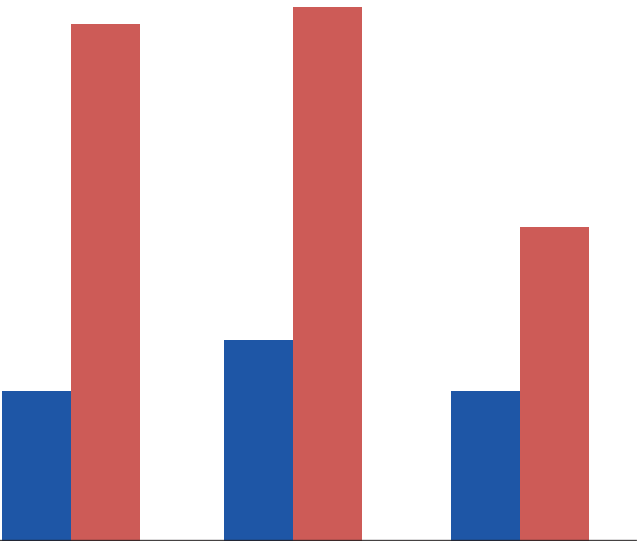

Figure 2. Number of paw licks (and percentage inhibition of licks) in rats administered with formalin and pretreated with Combretum sordidum extract 
Table 3. Abdominal writhing in mice intraperitonealy injected with acetic acid and pre-treated with Combretum sordidum

\begin{tabular}{|l|l|l|}
\hline Group & Number of Writhes & Inhibition (\%) \\
\hline Control & $43.6 \pm 2.22$ & 0 \\
\hline CS $100 \mathrm{mg} / \mathrm{kg}$ & $37.6 \pm 3.41$ & 13.76 \\
\hline CS $200 \mathrm{mg} / \mathrm{kg}$ & $25.3 \pm 4.90$ & 42.09 \\
\hline CS $400 \mathrm{mg} / \mathrm{kg}$ & $11.8 \pm 1.19$ & 73.05 \\
\hline Indomethacin $10 \mathrm{mg} / \mathrm{kg}$ & $10.5 \pm 0.83$ & 75.9 \\
\hline
\end{tabular}

Figure 3. Abdominal writhing in mice intraperitonealy injected with acetic acid and pretreated with Combretum sordidum

- Number of writhes

- Inhibition

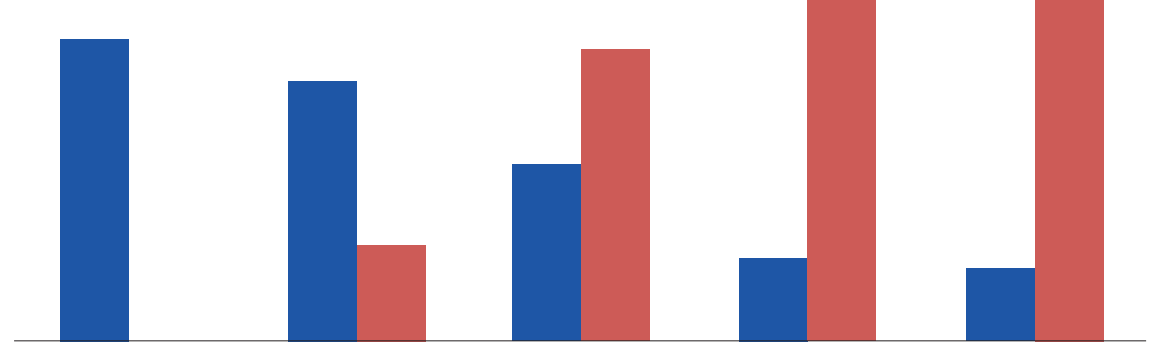


Table 4. Effect of Methanol-water, ethyl acetate, and Hexane fractions on acetic acid- induced abdominal writhing in mice

\begin{tabular}{|l|l|l|}
\hline Group & Number of writhes & Inhibition (\%) \\
\hline Control & $62.6 \pm 1.25$ & 0 \\
\hline Aspirin $15 \mathrm{mg} / \mathrm{kg}$ & $35.8 \pm 4.31$ & 42.8 \\
\hline $\mathrm{MeOH} 20 \mathrm{mg} / \mathrm{kg}$ & $39.0 \pm 3.53$ & 37.7 \\
\hline $\mathrm{MeOH} 50 \mathrm{mg} / \mathrm{kg}$ & $46.5 \pm 2.97$ & 25.7 \\
\hline EA $20 \mathrm{mg} / \mathrm{kg}$ & $35.4 \pm 1.67$ & 43.5 \\
\hline EA $50 \mathrm{mg} / \mathrm{kg}$ & $43.0 \pm 4.10$ & 31.3 \\
\hline Hex $20 \mathrm{mg} / \mathrm{kg}$ & $34.8 \pm 4.14$ & 44.4 \\
\hline Hex $50 \mathrm{mg} / \mathrm{kg}$ & $46.0 \pm 3.65$ & 26.5 \\
\hline
\end{tabular}

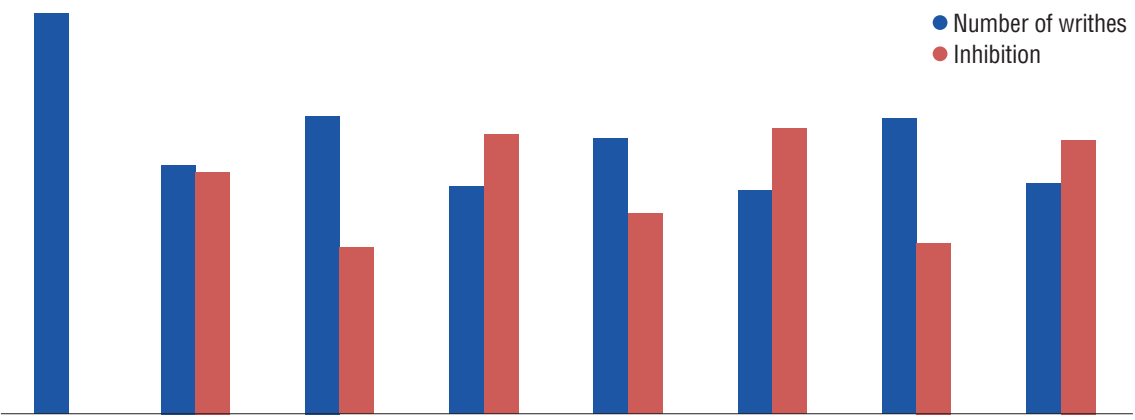

Figure 4. Effect of Methanol-water, ethyl acetate, and Hexane fractions on acetic acidinduced abdominal writhing in mice

In this study, acetone extract of $C$. sordidum demonstrated anti-inflammatory activities by inhibition of paw oedema formation after exposure to egg albumen and paw licking as a response to formalin-induced pain in rats. The anti-inflammatory response was comparable to that of indomethacin, a nonsteroidal anti-inflammatory drug used for treatment of arthritis, gout, bursitis. ${ }^{18}$ Egg albumen-induced paw oedema is an animal model of inflammation used to detect anti-inflammatory agents with activity in the acute phase of inflammation. ${ }^{19}$ This study demonstrated the anti-inflammatory effect of $C$. sordidum was significantly established by 60 minutes post-injection of albumen. This suggests anti-inflammation with activity in acute inflammatory phase. Findings from the formalin-induced paw lick model also corroborated the anti-inflammatory effect of C. sordidum. It further established a more marked anti-inflammatory activity in the late phase of inflammation, with significantly more profound anti-inflammatory action compared to the same indomethacin.

Formalin-induced paw lick model of inflammation demonstrates the interrelation of inflammation and nociception with distinct responses in the early 
and late phases of inflammation but mediated via different inflammatory pathways. ${ }^{20}$ The early phase is correlated with direct effect on peripheral nociceptors with minimal influence of prostaglandins. This stimulation in the early phase culminates in centrally mediated pain accompanied by release of substance $P .{ }^{21,22}$ The late phase is characterized by release of mediators of inflammation; histamine, prostaglandins, serotonin and bradykinin. ${ }^{23,24}$ The anti-inflammatory activity of $C$. sordidum is suggested to be mediated via the peripheral and central mechanisms of inflammatory pathways, and may involve inhibition of cyclooxygenase enzymes which are active players in the model. Centrally acting drugs such as opioids inhibit both phases equally but peripherally acting drugs such as cyclooxygenase inhibitors and corticosteroids only inhibit the late phase. ${ }^{25}$

The acetone extract of Combretum sordidum was also found to possess analgesic activities in this study with the significant inhibition of abdominal writhing in the pretreated mice. Acetic acid- induced writhing in mice is a commonly used model of analgesia in experimental animals for establishment of peripherally acting analgesic drugs which may involve stimulation of local peritoneal receptors. ${ }^{26,27}$ The crude extract of $C$. sordidum showed a dose-dependent and significant analgesic action when compared to the reference drugs, indomethacin and aspirin. Acetic acid causes pain by liberating endogenous substances that excite pain nerve endings. ${ }^{28}$

Pain sensation in acetic acid-induced writhing method is elicited by triggering localized inflammatory response resulting in release of free arachidonic acid from tissue phospholipids via cyclooxygenase (COX) and prostaglandin (PG) biosynthesis. ${ }^{29,30}$ The acetic acid - induced writhing has been specifically associated with increased level of $\mathrm{PGE}_{2}$ and $\mathrm{PGE}_{2} \alpha$ in peritoneal fluids as well as lipooxygenase products. ${ }^{31}$ The increase in prostaglandin levels within the peritoneal cavity then enhances inflammatory pain by increasing capillary permeability. The acetic acid- induced writhing method is effective to evaluate peripherally active analgesics. Agents which reduce the number of writhes will render analgesic effect probably by inhibition of prostaglandin synthesis, a peripheral mechanism of pain inhibition. ${ }^{32}$ Therefore, the result of this study shows that the extract possesses strong peripheral analgesic effect. Some of the phytoconstituents of this plant such as flavonoids, saponins, and tannins have been demonstrated to have significant pharmacological activities. ${ }^{33}$

Solvent partitioned fractions of $C$. sordidum extract (hexane, ethyl acetate and methanol-water fractions) demonstrated potent analgesic effect in acetic acidinduced writhing test in mice, with the hexane fraction showing the highest 
activity at $20 \mathrm{mg} / \mathrm{kg}$ body weight. Further purification of the hexane fraction yielded 7 fractions with fractions 6 and 7 showing marked inhibition of abdominal writhing, almost 2-folds of that observed in aspirin.

Extract of C. sordidum at all doses showed anti-inflammatory and analgesic activities which are comparable to that exhibited by indomethacin or aspirin. This study suggested that the anti-inflammatory effect of $C$. sordidum may be mediated via both peripheral and central mechanisms of inflammation. The solvent partitioned fractions showed hexane fraction had the most potent analgesic activity and further purification yielded 7 fractions. Fractions 6 and 7 showed remarkable analgesic effect with almost 2-folds of that observed for aspirin. The peripheral pathway for mediation of the analgesic effect of the extract, solvent-partitioned fractions and column fractions of hexane fractions was established also. This is a report of preliminary anti-inflammatory and analgesic activities of C. sordidum. Further studies are going on to purify, characterize and completely elucidate the structure of the bioactive compound in this extract, particularly bioactive compounds responsible for the remarkable analgesic activity of the fractions.

\section{REFERENCES}

1. Miguel, M. G. Antioxidant and Anti-Inflammatory Activities of Essential Oils: A short review. Molecules. 2010, 15, 9252-9287

2. Kusuma, I. W.; Kuspradini, H.; Arung, E. T.; Aryani, F.; Min, Y. H.; Kim, J. S.; Kim, Y. Biological Activity and Phytochemical Analysis of Three Indonesian Medicinal Plants, Murraya koenigii, Syzygium polyanthum and Zingiber purpurea. J. Acupunct. Meridian Stud. 2011, $4,75-79$.

3. Iwalewa, E. O.; McGaw, L. J.; Naidoo, V.; Eloff, J. N. Inflammation: the foundation of diseases and disorders. A review of phytomedicines of South African origin used to treat pain and inflammatory conditions. Afr. J. Biotechnol. 2007, 6, 2868-2885.

4. Plytycz, B.; Seijelid, R. From inflammation to sickness: historical perspective. Arch. Immunol. Ther. Exp. 2003, 51, 105-109.

5. Parham, C.; Chirica, M.; Timans, J.; Vaisberg, E.; Travis, M.; Cheung, J. Pflanz, S.; Zhang, R.; Singh, K. P.; Vega, F.; To, W.; Wagner, J.; O’Farrell, A. M.; McClanahan, T.; Zurawski, S.; Hannum, C.; Gorman, D.; Rennick, D. M.; Kastelein, R. A.; De Waal Malefyt, R.; Moore, K. W. A. receptor for the heterodimeric cytokine IL-23 is composed of IL-12Rbeta1 and a novel cytokine receptor subunit, IL-23R. J. Immunol. 2002, 168, 5699-5708.

6. Gao, H. M.; Hong, J. S. Why neurodegenerative diseases are progressive: uncontrolled inflammation drives disease progression. Trends Immunol. 2oo8, 29, 357-365.

7. Teresita Guardia, Alejandra Ester Rotelli, Ame' rico Osvaldo Juarez, Lilian Eugenia Pelzer (2001) Anti-inflammatory properties of plant flavonoids. Effects of rutin, quercetin and hesperidin on adjuvant arthritis in rat. Farmaco. 2001, 56, 683-687.

8. Baricevic, D. S.; Sosa, R.; Della Loggia, A.; Tubaro, B.; Simonovska, A.; Krasna, A.; Zupan- 
cic A. Topical anti-inflammatory activity of Salvia officinalis L. leaves: the relevance of ursolic acid. J. Ethnopharmacol. 2001, 75, 125-132.

9. Olaoluwa, O.; Ogunbor, F. Phytochemical screening, antimicrobial properties and essential oil constituents of Combretum sordidum Exell. Int. J. Pharm. Sci. Res. 2015, 6, 1176-1180.

10. Beaudelaire K. P.; Luciano, B.; Remy, B. T.; Marius, M.; Télesphore, B. N.; Hee-Juhn, P.; Kyung-Tae, L.; Leon, A. T. Polyhydroxyoleanane-type triterpenoids from Combretum molle and their antiinflammatory activity. Phytochem. Lett. 2oo8, 1, 183-187.

11. Teshome, T. D.; Ayana, A.; Sileshi, N.; Tadesse, W. Savanna land use and its effect on woody plant species diversity in Borana, Southern Ethiopia. Sci. Technol. Arts Res. J. 2012, $1,43-52$.

12.Eloff, J. N.; Katerere, D. R.; McGaw, L. J. The biological activity and chemistry of the southern African Combretaceae. J. Ethnopharmacol. 2008, 119, 686-699.

13. Aroke S. A.; Lyndy, J. M.; Esameldin, E. E.; Vinasan, N.; Jacobus, N. E. Polarity of extracts and fractions of four Combretum (Combretaceae) species used to treat infections and gastrointestinal disorders in southern African traditional medicine has a major effect on different relevant in vitro activities. J. Ethnopharmacol. 2014, 154, 339-350.

14. Magwenzi, R.; Nyakunu, C.; Mukanganyama, S. The Effect of Selected Combretum species from Zimbabwe on the growth and drug effux systems of Mycobacterium aurum and Mycobacterium smegmatis. J. Micr. Biochem.Technol. 2014, S3, 003.

15. Moyo, R.; Chimponda, T.; Mukanganyama, S. Inhibition of hematopoietic prostaglandin D2 synthase (H-PGDS) by an alkaloid extract from Combretum molle. BMC Complement. Altern. Med. 2014, 14, 221.

16. Ojewole, J. A. Cardiovascular effects of mollic acid glucoside, a 1 $\alpha$-hydroxycycloartenoid saponin extractive from Combretum molle $\mathrm{R}$ Br ex G Don (Combretaceae) leaf. Cardiovasc. J. Afr. 2008, 19, 128-134.

17. Eloff, J. N.; Famakin, J. O.; Katerere, D. R. P. Combretum woodii (Combretaceae) leaf extracts have high activity against Gram-negative and Gram-positive bacteria. Afr. J. Biotechnol. 2005, 4, 1161-1166.

18. Rubin, B. R.; Burton, R.; Navarra, S.; Antigua, J.; Londoño, J.; Pryhuber, K. G.; Lund, M.; Chen, E.; Najarian, D. K.; Petruschke, R. A.; Ozturk, Z. E.; Geba, G. P. Efficacy and safety profile of treatment with etoricoxib $120 \mathrm{mg}$ once daily compared with indomethacin $50 \mathrm{mg}$ three times daily in acute gout: A randomized controlled trial. Arthritis Rheum. 2004, 5O, 598-606.

19. Amos, S. B.; Chindo, I.; Edmond, P. A.; Wambebe, C.; Gamaniel, K. Anti-inflammatory and anti-nociceptive effects of Ficus platyphylla in rats and mice. J. Herbs Spices Med. Plants. 2002, 9, 47-53.

20. Oyebanji, B. O.; Saba, A. B.; Oridupa, O. A. Anti-nociceptive and anti-inflammatory activities of methanol extract of the leaves of Cajanus cajan. Niger. J. Physiol. Sci. 2014, 29, $183-188$

21. Shah, B. N.; Seth, A. K.; Maheshwari, K. M. A review on medicinal plants as a source of anti-inflammatory agents. Res. J. Med. Plants. 2011, 5, 101-115.

22. Oridupa, O. A.; Saba, A. B. Relative anti-inflammatory and analgesic activities of the who- 
le fruit, fruit bark, pulp and seed of Lagenaria breviflora Roberty. J. Pharm. Toxicol. 2012, 7, $288-297$.

23. Zeashana, H.; Amresha, G.; Raoa, C. V.; Singh, S. Antinociceptive activity of Amaranthus spinosus in experimental animals. J. Ethnopharmacol. 2009, 122, 492-496.

24. Alam, M. B.; Hossain, M. S.; Chowdhury, N. S.; Asadujjaman, M.; Zahan, R.; Islam, M. M.; Mazumder, M. E. H.; Haque, M. E.; Islam, A. Antioxidant, anti-inflammatory and antioyretic activities of Trichosanthes dioica Roxb. Fruits. J. Pharm. Toxicol. 2011, 6, 440-453.

25. Amanlou, M.; Dadkhah, F.; Salehnia A.; Farsam H.; Dehpour A. R. An anti-inflammatory and anti-nociceptive effect of hydroalcoholic extract of saturejakhuzistanicajamzad extract. $J$. Pharm. Sci. 2005, 8, 102-106.

26. Hasan, S. M. R; Hossain, M. M.; Akter, R.; Jamila, M.; Mazumder, M. E. H.; Alam, M. A.; Faruque, A.; Rana, S.; Rahman, S. Analgesic activity of the different fractions of the aerial parts of Commelina benghalensis Linn. Int. J. Pharmacol. 2010, 6, 63-67.

27. Ullah, M.; Showkat, N. U.; Ahmed, S. Evaluation of Momordica charantia L fruit extract for analgesic and anti-inflammatory activities using in vivo assay. Res. J. Med. Plant. 2011, 6, 236-244.

28. Duarte, I. D. G.; Nakamura, M.; Ferreira, S. H. Participation of the sympathetic system in acetic acid-induced writhing in mice. Braz. J. Med. Biol. Res. 1988, 21, 341-343.

29. Ahmed, F.; Hossain, M. H.; Rahman, A. A.; Shahid, I. Z. Antinociceptive and sedative effects of the bark of Cerberaodollam Gaertn. Orient. Pharm. Exp. Med. 2006, 6, 344-348.

30. Derardt, R.; Jougney, S.; Delevalccee, F.; Falhout, M. Release of prostaglandins E and F in an algogenic reaction and its inhibition. Eur. J. Pharmacol. 1980, 51, 17-24.

31. Zakaria, Z. A.; Abdul Gani, Z. D. F. Antinociceptive, anti-inflammatory, and antipyretic properties of an aqueous extract of Dicranopteris linearis leaves in experimental animal models. J. Nat. Med. 2008, 62, 179-187.

32. Ferdous, M.; Rouf, R.; Shilpi, J. A.; Uddin, S. J. Antinociceptive activity of the ethanolic extract of Ficus racemosa Linn. (Moraceae). Orient. Pharm. Exp. Med. 2oo8, 8, 93-96.

33. Egharevba, H. O.; Odigwe, A. C.; Abdullahi, M. S.; Okwute, S. K.; Okogun, J. I: Phytochemical analysis and broad-spectrum antimicrobial activity of Cassia Occidentalis (whole plant). N. Y. Sci. J. 2010, 3, 74-81. 